「我が社の技術革新」特集

\title{
紙を拓き，紙を築く 一十條製紙株式会社一
}

\author{
飯 田 清 昭
}

\section{1. 紙一古くて新しい商品}

2000年近くの歴史を持ち，文明の記録媒体として貴重 な存在であった紙は，ともすれば古いイメージをもたれ やすい。しかし，䄉維や鉄が同じような長い歴史を持 ち，しかも，新しい技術の集積体として存在するよう に，紙も社会の变化に対応し，技術の進歩を吸収・発展 させ，たえず新しく生れかわる産業として今日にいたっ ている。その外から見えない水面下の革新の例をいくつ か紹介してみたい。

\section{1 情報化社会}

現代を定義する言葉の一つとして，情報化があげられ る。このエレクトロニクスによる通信と情報処理の発展 は当然のことながら紙に大きな影響を与えつつある。

その一つの例をコンピューターのプリント・アウトで 見てみよう。現在高速ライン・プリンターが要求する紙 の品質は，(1) 1 万字/分の印字速度に耐えること，(2)折 りたたまれながらプリント・アウトされたフォーム用紙 が50～60cm 積み上げられ，横に倒れることがないこ と，(3)表面が平滑でありながら適当な摩擦があって滑ら ない事等で，今までの紙と全く異なったものである。し かも，価格が安いことの条件がつく。これらを満足する ため，かつ，それに刺激されて，製紙産業はより厳しい 品質レベル（6～- $\mathrm{m}$ の幅の紙の厚さの変動が士 2 ミク ロン) やパルプの配向性の管理等, 従来の生産技術を大 きく改善して答えてきている。

又、ファクシミリの急速な普及の裹には，小型でメイ ンテナンスの容易なハードを可能にした感熱記録システ ムがあり，それには，当社が完成した感熱紙の高品質・ 高信頼性がキメ手となっている。この感熱紙は外観上は 何の変哲もないが，その表面には熱により発色する塗工 層があり(厚さ 5 ミクロン)，その発色に必要なエネルギ 一は 0.4 ミリジュール/ドットにまで高感度化されてい る。

情報化社会の一つの特徵は, 情報が非常に軽くなった ことであろう。古くは文明として永久に保存される事を 期待されていたいかが重い情報から，一過性で必要な時 にだけ見る軽い情報の媒体としての用途が急增してい
る。したがってこの分野では従来と巽なった商品コンセ プトの紙（例えば薄くて情報のつめ込める紙や写真・カ ラー印刷に向いた紙）が求められ，それに対応する技術 開発が数多く工夫され，それぞれの目的に合った紙が圮 に出されている。

このように同じ紙でありながら，社会の変化につれ品 質要求が多様化・高度化し，それに当社を含め製紙産業 が对応することにより活性化し発展してきたと言える。

情報化社会との関倸では、ペーパーレスにふれざるを 得ない。詳細に考察するには紙面がないが, 情報化社会 は新しい紙のニーズを生み出しており，エレクトロニク 不媒体と共に発展するであろう。

\section{2 生産技術}

生産技術の面でも製紙産業は大きく変身している。そ の例を新聞用䌅で見てみたい。現在では，回収新閏古絋 が原料の50\%にまでなっている。これは，古紙回収のシ ステム化，再パルプ化等の技術開発が寄与している。 又，抄紙機を大型化 (幅 $8.5 \mathrm{~m})$, 高速化 $(1300 \mathrm{~m} /$ 分) し, コスト・ダウンを可能にした。一方，新聞社での印刷入 ピードは12万部/時にまでなり，1.6m 幅の巻取 8 本が同 時に表塞を印刷され，重ねられ折りたたまれ，積及重ね

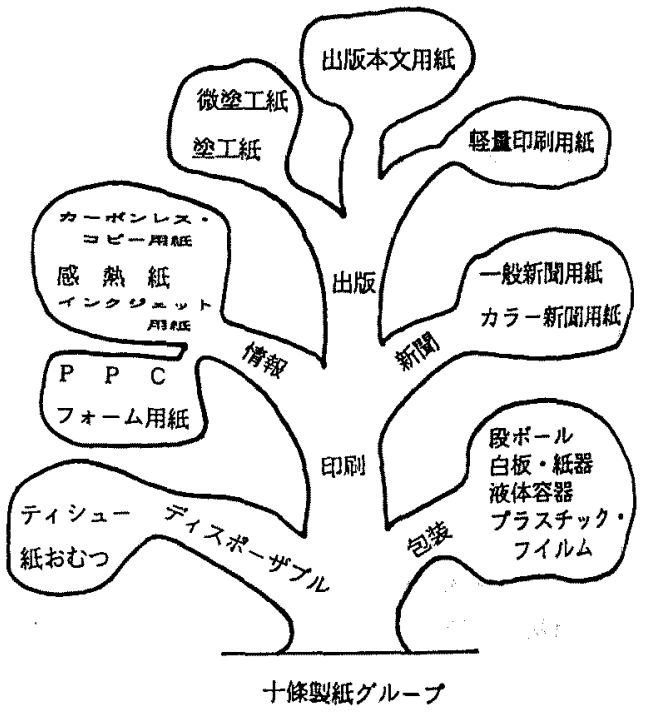

図1十條製紙ダループの多角化 
られ出荷される。この複雑な高速下での無人作業を渵足 する秖の品質要求は縤しく，全く新しい生産技術がこれ を解決したとも言える。

このような製品の高信頼性化は，日本のあらゆる産業 で起きているが，製紙産業も同じようにダイナミックに 発展してきたと言える。

\section{2. 十條製妹の展開}

\section{1 角化}

当社を社会の発展・多梯化をビジネス・チャンスとし て積極的に多角化を進めてきている(図参照)。これらの 新しい事業への進出は，若い能力のある技術者の活躍の 場であり，その成果が企業をささえている。その具体例 として，情報用紙への進出を述べてみたい。

この分野はまずカーボンレス複写用紙に始まる。これ はロイコ染料を微細なカプセルにし紙の表面に盗工す る。このカブセルが圧力（例えば筆生）で破れるとロイ コ染料が発色する。そこには，染料を中心とした有機化 学の深い知見が要求される。一方，この基礎技術を商品 として大量生産するには，全く別の工学（例えば小さな 圧力で破れるカプセルをいかに高速で均一に登工する か）が必要となる。又，この製品は最終時には伝票に加 工されるためその加工適性が必要であり，さらに，部分 的に発色を报える減感インクの開発等地味ではあるが多 くの技術の複合体で，それは，研究者，技術者の熱意と 努力で䓂打されている。

ついで,このカーボンレス複写紙の技術から感熱紙の 技術が開発された。当社はそのパイオニアであり, 現在 もそのリーダーである。それは，より小型により速くを 要求するプリンターに対し，挑戦的に受けて立った意欲 と熟意の結果であり，それが世界に受け入れられる技術 を生んだと言える。

このような機会は情報用紙にかぎらずまだ無限に広が っており，若い力の活躍を待っている。

\section{2 コンピューター}

近年の技術革新の源泉はコンビューターと言ってよい であろう。当社もその応用を積極的に取り上げてきてい る。その一例を以下に紹介する。

トータル・ミルワイト・コントロール：工程管理にプロ セス・コンピューターは広く使用されているが，それを 一歩ふみ出し，当社最大の生産工場（日座量1500t）全 体をオン・ラインで管理しようとする野心的な試みで， 現在第二段階に入っている。そのねらいは管理の合理化
で, 計量管理の徹底，全工場の操業状況の把握，情報の 普遍化等を可能にする。但し、システムは決して機械的 なものでなく，オペレーターに，オペレーター・ワーク ステーションを提供し，その判断を最大限に活用しよう とする。

今後ともコンピューターの利用はかぎりない可能性と 技術の広がりを与えてくれるであろう。

\section{3 研究開発 $(R \& D)$ の充実}

研究開発は企業にとって生命線であり，その活性度が 将来を左右する。当社もその充実をはかっているが，内 容を簡単に紹介してみたい。

商品に対し高品質・高信頼性が要求されるにつれ, 研 究部門の分析能力・解析能力をより高める必要があり, 分析機器の拡充, LAN の遒入等を積極的に行なってい る。又, 生産設備の高速化・複雑化に対応するため, 実 機をシミュレーションできる種々の大型・高速のテス ト・プラントをそろえている。これらの設備の価值はそ れを使う人に依るが，当社では有効に活用され大きな戦 カとなっている。

一方，社会のニーズが多様化していくことから， R\& Dのテーマは幅広く，単に印刷用紙のみならず情報関連 産業基材，植物関連，システム技術開発等にまでおよん でいる。

\section{3. これからの挑戦}

このように，製紙産業においても新商品開発，技術革 新に多くの若い人々のエネルギーが向けられ，その結果 として国内的にも国際的にも重要な地位（世界第 2 位の 紙生産国）を占奴る。

それでは，これからは何をめざすのであろうか？ 紙 というライフ・サイクルが永く, 大量生産される商品で は信頼性の向上，コスト・ダウンが大きな目標であり， これを可能にする技術は追求され权ばならず，又，そこ に大きな活動の場が生まれてくる。

しかし，同時に企業の未来のために R \& D は必要で あり，当社として，(1)次世代コンピューター技術，(2)バ イオテクノロジー, (3)新素材開発の三つを柱として考え ている。これらは，全社的な長期構想の中でオーソライ ズされ，育成されつつある。

科学、工学を問わず，その原点は新しいことへの挑戦 である。そして当社の前途にも無限にその分野が広がっ ており，若い研究者・技街者の活躍を待っている。 